\title{
Poor Appetite in School Children: Is It a False Perception of Parents?
}

\section{Okul Çağı Çocuklarında Iștahsızlık Sorunu: Ailelerin Yanlıș Algısı mı?}

\author{
Nazan Kaymaz1, Nurcan Bulur2, Şule Yıldırım1, Sibel Cevizci1, Naci Topaloğlu1, \\ Mustafa Tekin1, Fatih Köksal Binnetoğlu1, Elif Nursel Özmert3 \\ ${ }^{1}$ Çanakkale Onsekiz Mart University Faculty of Medicine, Department of Pediatrics, Çanakkale, Turkey \\ 2 Mardin Women and Children Hospital, Clinic of Pediatrics, Mardin, Turkey \\ ${ }^{3}$ Çanakkale Onsekiz Mart University Faculty of Medicine, Department of Public Health, Çanakkale, Turkey \\ 4 Hacettepe University Faculty of Medicine, Department of Pediatrics, Social Pediatrics Unit, Ankara, Turkey
}

\begin{abstract}
Aim: Poor appetite is a common symptom in childhood that can either be organic or nonorganic. Prolonged poor appetite may affect children's growth negatively. However picking at food or refusing to eat stresses parents out. In this study, we aimed to investigate the relationship between parental perception of the child's body measurements and appetite in school children who were admitted to the outpatient clinic with the complaint of sustained poor appetite.

Materials and Methods: A total of 105 school children (6-15 years old) with the complaint of poor appetite who were investigated several times previously with no organic reason were included in the study. The study was conducted with a questionnaire that was filled out by parents recording demographics. Anthropometric measurements including body weight and height were measured by the same researcher. Body mass index was calculated and BMIfor-age was determined. Patients with normal BMI percentile values and patients with low BMl percentile values were compared.

Results: 105 children (M/F: 51/54) with a mean age of $8.2 \pm 1.9$ years were studied. Mean body weight and height of children were $23.8 \pm 5.7 \mathrm{~kg}$ and $124.1 \pm 11.6 \mathrm{~cm}$, respectively. Mean BMl of children was $15.2 \pm 1.5$. According to $\mathrm{BMl}$ percentiles $65.7 \%(n=69)$ of children were normal weight, $30.5 \%$ $(n=32)$ were underweight, and $3.8 \%(n=4)$ were overweight. When compared in terms of BMl percentiles no difference was found between the groups. Conclusion: Perception of the parents of their children's growth is influenced by many factors and usually does not reflect the facts. In our study, we found that the majority of the children with poor appetite were in normal weight range according to BMl percentile. Nevertheless, nearly one third of the children were underweight, a fact that should not be ignored. The Journal of Pediatric Research 2015;2(1):11-6

Key Words: Poor appetite, children, parental perception
\end{abstract}

Conflicts of Interest: The authors reported no conflict of interest related to this article.

\section{ÖZET}

Amaç: Çocukluk çağında iştahsızlık sık bir yakınma olup, organik ya da patolojik nedenlere bağı olabilir. Uzun süreli iştahsızlık büyümeyi etkileyebilmekle birlikte aileleri sıkıntıya sokan bir durumdur. Bu çalışmada iştahsızlık yakınmasıyla polikliniğe getirilen okul çağı çocuklarında vücut ölçümleri ile aile algısı karşılaştırıldı.

Gereç ve Yöntem: Çalışmaya daha önce en az 2 kez iştahsızlık şikayetiyle polikliniğe getirilen ve altta yatan organik neden saptanmayan, bilinen hastalığı olmayan 105 çocuk (6-15 yaş) dahil edildi. Aileler tarafından çalışmaya spesifik hazırlanmış demografik özellikleri ve süt çocukluğu dönemindeki beslenme özelliklerini içeren anket dolduruldu. Hastaların antropometrik ölçümleri alınarak vücut kitle indeksleri (VKI) hesaplandı. VKI persantil değerleri normalin altında ve normal olan hastalar karşılaştırıldı. Bulgular: Ortalama yaşı 8,2+1,9 yıl olan 105 hasta (51 erkek, 54 kIz) çalışmaya dahil edildi. Hastaların ortalama VKI değerleri $15,2 \pm 1,5$ idi. VKI persantil değerine göre \%65,7 (n=69) hasta normal, \%30,5 (n=32) hasta düşük ağırıkı olup, \%3,8 (n=4) hasta ise fazla kilolu idi. Bu hastaların demografik ve süt çocukluğundaki beslenme özellikleri karşılaştırdığında fark saptanmadı. Sonuç: Çocuklarının büyüme konusunda ebeveynlerin algısı pek çok faktörden etkilenir ve genellikle gerçeği yansıtmaz. Bu çalışmada, iştahsızlık şikayeti ile getirilen çocukların büyük kısmının VKI persantil değerlerinin yaşına göre normal aralıkta olmasına rağmen yaklaşık üçte birinin zayıf olduğu görüldü. Organik bozukluk saptanmayan, normal fizik muayene bulguları olan hastalarda aile algıının göz ardı edilmemesi gerektiğini düşünmekteyiz. The Journal of Pediatric Research 2015;2(1):11-6

Anahtar Kelimeler: |ştahsızık, çocuk, aile algısı

Çıkar Çatışması: Yazarlar bu makale ile ilgili olarak herhangi bir çıkar çatışması bildirmemiştir. 


\section{Introduction}

Refusal to eat and having a poor appetite are common behaviors among children that stress parents. It may be due to emotional need for mother's care or in order to show growing autonomy, to show anger towards the mother or to attract attention. Between $20-35 \%$ of healthy children have eating problems (1). Usually, the children eat enough, but that does not fulfill parental expectations, especially if they have overweight siblings (2).

Although it can be a sign of an organic problem that results in failure to thrive, many cases of poor appetite still have normal growth (3). Poor appetite and weight gain should be assessed together.

In some societies, to be overweight or have a large body is more respectable. It may be the perception of normality for those parents and they evaluate the growth of their children based on this $(4,5)$. Most of parents cannot estimate their child's weight status correctly most of time (6-8). In this study, we aimed to investigate the relationship between parental perception of their child's body measurements and appetite in school-age children who were admitted to the outpatient clinic with the complaint of poor appetite.

\section{Materials and Methods}

\section{Study Design}

One hundred and five school-age children (6-15 years old) who had been previously investigated several (at least 2) times for poor appetite and with no organic reason were included in the study. The investigations included complete blood count, blood chemistry, urinalysis, urine culture, vitamin B12 and folic acid levels, thyroid function tests, antigliadin antibodies, stool parasite tests and abdominal ultrasonography. All the participants were healthy children and had no complaint except poor appetite. This study was performed with questionnaires completed by parents. People who could not recall the answers to any of the survey questions were excluded from the study. Participants had normal physical examination findings, and were treated with multivitamin, zinc and iron therapy at least 1 month in the previous year but did not develop any change in their level of appetite.

\section{The Content of the Questionnaire}

The questions were asked by one person in a separate room and answered by parents. The parents of children who agreed to participate in the study were asked questions on a survey form filled out during a face-to-face interview. The questions collected information about the child's name, age, gender, gestational week at birth, type of birth, birth weight, infant feeding habits, maternal age and education, socioeconomical status of the family. People who could not recall the answers to any of the survey questions were excluded from the study. Informed consent was obtained from the families.

\section{Anthropometric Measurements}

Anthropometric measurements including body weight and height were measured by the same researcher (I.E).
Participants were weighed in their underwear, without external clothing. Height was measured standing using the standard measurements. Body mass index (BMI) was calculated as the ratio of weight to the square of height $(\mathrm{kg} /$ $\mathrm{m} 2$ ). The reference values that was created for the Turkish children was used to determine children's age- and sexspecific percentiles for weight, height and BMI (9).

\section{Excluding Criteria}

Children with chronic illness, abnormal laboratory findings and patients whose family practiced the method of punishment for not eating and reward after eating were excluded.

\section{Statistical Analysis}

Statistical analyses were performed using SPSS software version 19.0. Descriptive statistics (frequencies, percentages, means, and standard deviations) were used to describe groups of numerical data and the basic features of the data. The variables were investigated using visual (histograms, probability plots) and analytical methods (KolmogorovSimirnov/Shapiro-Wilk's test) to determine whether or not the data was normally distributed. Since the variables BMI, birth weight, mother's age, duration of breastfeeding, duration of formula intake, beginning time of cow's milk, duration of pacifier usage and number of children in the family were not normally distributed; Mann-Whitney $U$ nonparametric test was conducted to compare these parameters between the groups. Chi-square test and Fisher's Exact Test were used to examine the association between categorical variables.

\section{Results}

A total of 105 children (M/F: 51/54) with a mean age of $8.2 \pm 1.9$ years were included in the study. Demographic characteristics of the patients are summarized in Table I.

Fifty-four point eight percent of the patients received breast milk longer than 12 months. The mean of total duration of breast milk was $15.1 \pm 8.2$ months. There was statistically significant correlation between duration of breastfeeding and $\mathrm{BMI}$ percentiles (Kendall's correlation $=0.218, \mathrm{p}=0.015$ ).

The average number of children in families was 4.1 children (min-max: 1-9). The mean number of siblings of patients was $4.1 \pm 2.0$. In our study most of the patients $(32.4 \%)$ were the eldest child in the family. There was no statistically significant difference between number of siblings and BMI percentiles of patients.

In the study, timing of introduction of complementary feeding was 7.9 \pm 2.1 (min: 4-max: 12) months. The most common time was at six months $(n=28)$. However, $52.4 \%$ of patients began complementary feeding after eight months.

When classification of children's weight was asked to mothers, all of them thought that their children were wasted (Figure 1). So $69.5 \%$ of the mothers' had a false perception of their child's feeding status. The characteristics of children, characteristics of feeding during infancy period and characteristics of mothers were summarized in Table II, III and IV. 


\section{Discussion}

Poor appetite is a common symptom in childhood. In the evaluation of pediatric patients admitted with poor appetite it is important to record a detailed diet, developmental and family history. As growth and development continues in children they can be affected by nutritional deficiencies more than other age groups. The percentage of healthy children admitted with the complaint of poor appetite is 20-35\% (10).

In our study group all children defined as wasted by their mothers were found to be mostly normal weight. This finding makes us think that the energy content consumed per meal by children is sufficient. In a study, the frequency of eating and portion sizes of children were compared and the energy content was found to be inversely proportional to the portion size in children up to 11 months of age (11). As a result, while the mother may think that her children don't eat, the child may consume small portions with high energy content. Fox et al. (11) reported that children can control their own energy in take, therefore to insist on feeding a child can damage this control. Similarly, Kral et al. (12) showed that children aged 3-6 years can regulate their energy intake.

\begin{tabular}{|l|l|}
\hline \multicolumn{2}{|l|}{ Table I. Characteristics of the Study Population } \\
\hline Variables & Mean \pm SD \\
\hline Age (years) & $8.2 \pm 1.9$ \\
\hline Body weight $(\mathrm{kg})$ & $23.8 \pm 5.7$ \\
\hline Height $(\mathrm{cm})$ & $124.1 \pm 11.6$ \\
\hline BMl percentiles & $15.2 \pm 1.5$ \\
\hline Mother age & $33.3 \pm 6.4$ \\
\hline Birth weight (gr) & $3092.9 \pm 465.5$ \\
\hline Duration of breastfeeding (mo) ${ }^{*}$ & $15.1 \pm 8.2$ \\
\hline Duration of formula intake (mo) ${ }^{* *}$ & $15.5 \pm 7.7$ \\
\hline Timing of complementary feeding (mo) & $7.9 \pm 2.1$ \\
\hline Timing of beginning cow's milk feeding (mo) ${ }^{* * *}$ & $11.0 \pm 5.9$ \\
\hline Number of children in the family & $4.1 \pm 2.0$ \\
\hline Total number of children & 105 \\
\hline
\end{tabular}

*: 10 nonbreastfed children, ${ }^{* *}: 61$ non formulafed children, ${ }^{* * *}: 64$ not intake of cow's milk
Families may show more interest in their first child. In our study most of the patients (32.4\%) were the eldest child in the family. As the number of children increases, parents' experience increases. However, individual care and attention to each child may decrease. Bayrı et al. (13) reported that as the number of siblings increase the incidence of malnutrition also increases. However, in our study there was no statistically significant difference between number of siblings and BMI percentiles of patients.

Studies showed that weight status of boys are more likely to be underestimated by parents compared to girls $(14,15)$. Social values seem to be effective in this respect. While weight and body image of girls are more considerable by mothers, it is thougt to be a physical advantage in terms of boys. In the present study $51 \%$ of children were girls and there was no difference between sexes with respect to BMI.

\begin{tabular}{|l|l|l|l|}
\hline \multicolumn{4}{|l|}{ Table II. Some characteristics of children in two groups } \\
\hline & $\begin{array}{l}\text { Group 1 } \\
(\mathbf{n}=32)\end{array}$ & $\begin{array}{l}\text { Group 2 } \\
(\mathbf{n}=73)\end{array}$ & \\
\hline Variables & $\mathrm{n}(\%)$ & $\mathrm{n}(\%)$ & $\mathrm{p}^{*}$ \\
\hline Child's age group & & & \\
\hline 6-12 years & $29(29.6)$ & $69(70.4)$ & 0.433 \\
\hline$\geq 12$ years & $3(42.9)$ & $4(57.1)$ & \\
\hline Sex & & & \\
\hline Girls & $15(27.8)$ & $39(72.2)$ & 0.537 \\
\hline Boys & $17(33.3)$ & $34(66.7)$ & \\
\hline Delivery type & & & \\
\hline NSVD & $29(33.7)$ & $57(66.3)$ & \\
\hline C/S & $3(15.8)$ & $16(84.2)$ & 0.171 \\
\hline Birth weight & & & \\
\hline$<2500$ g. & $2(28.6)$ & $5(71.4)$ & \\
\hline $2500-4000 \mathrm{~g}$. & $29(30.2)$ & $67(69.8)$ & 0.829 \\
\hline$\geq 4000 \mathrm{~g}$. & $1(50.0)$ & $1(50.0)$ & \\
\hline Total number of children & $32(30.5)$ & $73(69.5)$ & 105 \\
\hline
\end{tabular}

*: Chi-Square Tests, Group 1: Children who were wasted according to BMI measurement Group 2: Children who were normal in weight according to BMI measurements, NSVD: Normal spontaneous vaginal delivery, $\mathrm{C} / \mathrm{S}$ : Caesarean section

Table III. Some feeding characteristics of children during infancy period

\begin{tabular}{|l|l|l|l|}
\hline \multicolumn{2}{|l|}{ Table III. Some feeding characteristics of children during infancy period } & Group $\mathbf{2}(\mathbf{n}=\mathbf{7 3})$ \\
\hline Variables & Group 1 $(\mathbf{n = 3 2})$ & Mean \pm SD & $\mathbf{p}^{\text {* }}$ \\
\hline Duration of breastfeeding $(\mathrm{mo})^{\mathrm{a}}$ & Mean \pm SD & $15.24 \pm 8.03$ & 0.886 \\
Duration of formula intake $(\mathrm{mo})^{\mathrm{b}}$ & $14.90 \pm 8.69$ & $14.00 \pm 10.49$ & 0.949 \\
Timing of complementary feeding $(\mathrm{mo})$ & $15.00 \pm 5.02$ & $7.75 \pm 2.53$ & 0.572 \\
Timing of beginning cow's milk feeding $(\mathrm{mo})^{\mathrm{c}} \mathrm{c}$ & $6.83 \pm 2.14$ & $11.33 \pm 6.73$ & 0.376 \\
\hline Total number of children & $10.10 \pm 7.09$ & 73 & 105 \\
\hline
\end{tabular}

Group 1: Children who were wasted according to BMI measurement, Group 2: Children who were normal in weight according to BMI measurements, a: Nonbreastfed children was 2 for group 1 and 8 for group 2, b: Non formula fed children was 18 for group 1 and 43 for group 2, c: 22 children had not intaken of cow's milk for group 1 and 42 for group 2 


\begin{tabular}{|c|c|c|c|c|c|}
\hline \multirow[b]{2}{*}{ Variables } & \multicolumn{2}{|c|}{ Group $1(n=32)$} & \multicolumn{2}{|c|}{ Group $2(n=73)$} & \multirow[b]{2}{*}{$p$} \\
\hline & Mean $\pm S D$ & Median (min-max) & Mean \pm SD & Median (min-max) & \\
\hline \multirow[t]{2}{*}{ Mother age } & $33.84 \pm 6.83$ & $32.00(24.00-47.00)$ & $33.07 \pm 6.29$ & $32.00(21.00-50.00)$ & $0.777^{* *}$ \\
\hline & $\mathrm{n}$ & $\%$ & $n$ & $\%$ & $\mathrm{p}$ \\
\hline \multicolumn{6}{|l|}{ Mother age } \\
\hline $20-35$ years & 23 & 31.5 & 50 & 68.5 & \\
\hline$>35$ years & 9 & 28.1 & 23 & 71.9 & $0.729^{*}$ \\
\hline \multicolumn{6}{|c|}{ Gravida of pregnancy } \\
\hline First & 10 & 29.4 & 24 & 70.6 & \\
\hline Second & 7 & 35.0 & 13 & 65.0 & $0.888^{*}$ \\
\hline$\geq 3$ & 15 & 29.4 & 36 & 70.6 & \\
\hline \multicolumn{6}{|c|}{ Gestational age at birth (wk) } \\
\hline$<37$ & - & - & 5 & 100 & \\
\hline$\geq 37$ & 32 & 32.0 & 68 & 68.0 & $0.320^{*}$ \\
\hline \multicolumn{6}{|c|}{ Mother's education status } \\
\hline$\leq 8$ years & 18 & 32.1 & 38 & 67.9 & \\
\hline$>8$ years & 14 & 28.6 & 35 & 71.4 & $0.692^{*}$ \\
\hline
\end{tabular}

*: Chi-Square Tests, ${ }^{* *}$ Mann-Whitney U Test group 1: Children who were wasted according to BMI measurement, Group 2: Children who were normal in weight according to BMI measurements

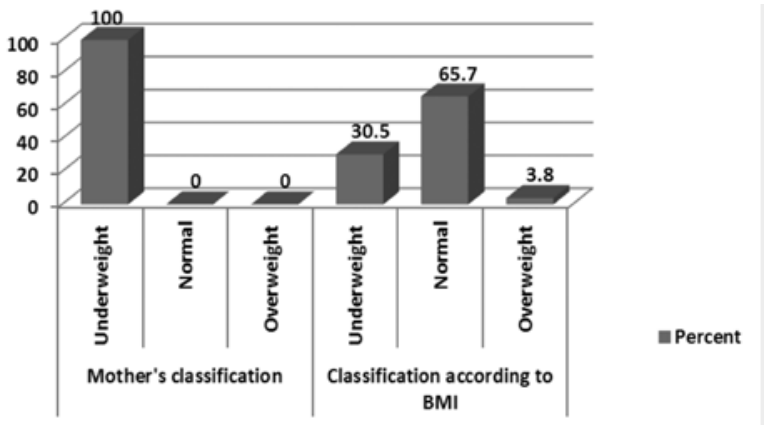

Figure 1. Measured BMl percentiles of children compared with mothers' thought

Lee et al. (16) found that appetite status reported by mothers was found to be compatible with calorie intake and weight gain among Korean school-age children. In the same study, the authors also emphasized that it is necessary to rely on the determination of parents regarding appetite state and that the regulation of nutritional status should be done according to the parents' opinions (16). In our study we found that $65.7 \%$ of children with poor appetite were in normal weight range according to $\mathrm{BMI}$ percentile, nevertheless $30.5 \%$ of children were wasted, a fact that should not be ignored.

In a survey including 455 children at 30 -months old, $89(20 \%)$ children had eating problems according to their parents, with the most common problems; $17 \%$ accepting a limited number of nutrients, $13 \%$ prefer drink to eat, $8 \%$ picky eaters, $6 \%$ chewing a long time, and $5 \%$ of participants were not interested in meals. According to that study; eating behavior problems may be a normal part of children's development in this period. In the same study, it was also determined that children with eating problems were more wasted and shorter than the children without poor appetite and the study showed that drinking more milk may reduce appetite (17).

Children's characteristics such as age, sex and measured weight status as well as mothers' educational level all influence the maternal/parental misperception $(6,7,18)$. Baughcum et al. (7) revealed that mothers educational level is associated with the classification of their children's weight status. High educational level implies a better knowledge. Moreover, higheducated mothers are more likely to be aware of the physical, social and emotional consequences of obesity, in both very young children and adults. Five $(4 \%)$ mothers in our study were university graduated, 44 mothers were high school graduated. The low number of postgradutes in our study may indicate indirectly that high educational level of mothers is associated with more correct classification of their child's weight status or that high-educated mothers better compete with this situation. In the present study, mother's educational status of the patients was clasified in two groups as less than 8 years and more than 8 years. There was no statistically significant difference according to 8 years between two groups.

Hendricks et al. (19) reported that mothers forcing children to eat is a risk factor affecting weight gain negatively. 
Therefore, foods should be offered to children, but the child must make the decision as to which food nutrients should be eaten (20).

In a study it was detected that feeding with only breast milk for a long time may cause malnutrition (21). In our study, the average duration of feeding with breast milk only was 7.9 2.1 (4-12) months.

Beginning complementary foods more after the sixth month may lead to malnutrition (22). It is known that a delay in starting complementary feeding can cause deficiency of energy and iron intake. A baby's growth rate gradually reduces after the $6^{\text {th }}$ month but because of their increased activity, their energy requirements also increase. Chewing skills may not be gained if complementary food intake does not start on time and important nutritional problems may occur in the future. In addition, iron deficiency anemia is more common when complementary feeding is delayed after the $6^{\text {th }}$ month. In our study, the average month for starting complementary feeding was $7.9 \pm 2.1$. When participants were separated into two groups, complementary feeding begun before and after 8 months, there was no statistically significant difference between the two groups in terms of BMI percentiles.

Recent studies indicate that zinc supplementation can increase both body weight and height. This effect is more prominent in children with malnutrition and is also associated with increased appetite and decreased infections (23). In our study, the participants were treated with administration of zinc, multivitamins and iron for at least 1 month during the previous one year and did not notice a positive change in the level of appetite.

Our findings should be understood in the context of some limitations. First, this is a regional study of appetite and the results may not generalize to other areas of Turkey. Therefore, cases found in the top socio-economic group may not be sufficiently represented. Secondly, socioeconomic status was not extensively evaluated in this study.

\section{Conclusion}

In conclusion, children who apply to outpatient clinics with poor appetite should be evaluated to see if there is also growth and development retardation and whether there is an underlying organic cause or not. Many parents' expectations about feeding their children may differ from real nutrition and growth status. Usually, the children eat enough, but that does not fulfill parental expectations. Similar to our findings, although many children can have normal development, children may be brought to the physician because they reject parents' requests. In such cases, it should be explained to the family that the growth rate of each child is different and this capacity might be influenced by genetic factors. The child's diet must be arranged according to the needs of the child and the appetite of the child must be respected during feeding. Mistaken attitudes in child feeding may result in picky eating behavior or rejection of some foods.

\section{References}

1. Chatoor I, GanibanJ. Food refusal by infants and young children: diagnosis and treatment. Cogn Behav Pract 2003; 10: $138-46$

2. Campbell MW, Williams J, Hampton A, Wake M. Maternal concern and perceptions of overweight in Australian preschool-aged children. Med J Aust 2006; 184: 274-7.

3. Wright CM, Parkinson KN, Shipton D, Drewett RF. How do toddler eating problems relate to their eating behavior, food preferences, and growth? Pediatrics 2007; 120: e1069-75.

4. Kumanyika S, Wilson JF, Guilford-Davenport M. Weightrelated attitudes and behaviors of black women. J Am Diet Assoc 1993; 93: 416-22.

5. Jain A, Sherman SN, Chamberlin LA, Carter Y, Powers SW, Whitaker RC. Why don't low-income mothers worry about their preschoolers being overweight? Pediatrics 2001; 107: 1138-46.

6. Maynard LM, Galuska DA, Blanck HM, Serdula MK. Mothers' perceptions of weight status of children. Pediatrics 2003; 111: 1226-31.

7. Baughcum AE, Chamberlin LA, Deeks CM, Powers SW, Whitaker RC. Mothers' perceptions of overweight preschool children. Pediatrics 2000; 106: 1380-6.

8. Carnell S, Edwards C, Croker H, Boniface D, Wardle J. Parental perceptions of overweight in $3-5$ y olds. Int $\mathrm{J}$ Obes (Lond) 2005; 29: 353-5.

9. Neyzi $O$, Günöz H, Furman A, Bundak R, Gökçay G, Darendeliler F, Baş F. Türk çocuklarında vücut ağırlığı, boy uzunluğu, baş çevresi ve vücut kitle indeksi referans değerleri. Çocuk sağlığı ve Hastalıkla $\neg$ rı Dergisi 2008; 51: $1-14$.

10. Ünal F. Iştahsız Çocuğa Yaklaşım. Güncel Pediatri 2011; 9: 79-84.

11. Fox MK, Devaney B, Reidy K, Razarnorakoto C, Ziegler $P$. Relationship between portion size and energy intake among infants and toddlers: evidence of self regulation. J Am Diet Assoc 2006; 106: 77-83.

12. Kral TV, Stunkard AJ, Berkowitz RI, Stallings VA, Brown DD, Faith MS. Daily food intake in relation to dietary energy density in the free- living enviroment: a prospective analiysis of children born at different risk of obesty. Am J Clin Nutr 2007; 86: 41-7.

13. Bayrı S. 0-24 Aylık Çocuklarda Malnütrüsyon Prevalansı ve Bunu Etkileyen Faktörler. Uzmanlık Tezi. Hacettepe Ün, Tıp Fak. Toplum Hekimliği Bilim Dalı. Ankara, 1980.

14. Jeffery AN, Voss LD, Metcalf BS, Alba S, Wilkin TJ. Parents' awareness of overweight in themselves and their children: cross sectional study within a cohort (EarlyBird 21). BMJ 2005; 330: 23-4.

15. Campbell MW, Williams J, Hampton A, Wake M. Mothers' concern and perceptions of overweight in Australian preschool-aged children. Med J Aust 2006; 184: 274-7.

16. Lee K, Song YM. Parent-reported appetite of a child and the child's weight status over a 2-year period in Korean children. J Am Diet Assoc 2007; 107: 678-80.

17. Wright CM, Parkinson KN, Shipton D, Drewett RF. How do toddler eating problems relate to their eating behavior, food preferences, and growth? Pediatrics 2007; 120: e1069-75.

18. Huang JS, Becerra K, Oda T, Walker E, Xu R, Donohue, M, Chen I, Curbelo V, Breslow A. Parental ability to discriminate the weight status of children: results of a survey. Pediatrics 2007; 120: e112-9.

19. Hendricks K, Briefel R, Novak T, Ziegler P. Maternal and child characteristics associated with infant and toddler feding practices. J Am Diet Assoc 2006; 106: 135-48. 
20. Orrell-Valente JK, Hill LG, Brechwald WA, Dodge KA, Pettit GS, Bates JE. "Just three more bites": an observational analysis of parents' socialization of children's eating at mealtime. Appetite 2007; 48: 37-45.

21. Özçalışkan A, Gürel, G, Soysal T. Malnütrüsyonlu Cocuklarda Serum ve Idrarda Magnezyum Değerleri. Atatürk Ün Tıp Fak Bül 1979; 11: 199.
22. Örten K. Yiğittaşı Sağlık Ocağı Bölgesi'nde 0-24 Aylık Çocukların Beslenme Büyüme ve Gelişme durumu Üzerine Bir Araştırma. Uzmanlık Tezi. Atatürk Ün.Tıp Fak. Halk Sağlığı Anabilim Dalı. Erzurum, 1984.

23. Umeta M, West CE, Haidar J, Deurenberg P, Hautvast JG. Zinc supplementation and stunted infants in Ethiopia, a randomised controlled trial. The Lancet 2000; 355: 2021-6. 